\title{
Construindo a história na televisão: Marc Ferro e os Cinejornais em Histoire Parallèle
}

\author{
Sheila Schvarzman[1]
}

\begin{abstract}
Resumo
Em 1989, quando a Europa se transformava com a Queda do Muro de Berlim e a expansão das comunicações via satélite, surge $L a$ Sept, o canal de televisão franco-alemão. Histoire Paralèlle, programa apresentado por Marc Ferro com os cinejornais veiculados nos dois países, 50 anos antes, se torna o programa de maior audiência da emissora, confrontando nas imagens os modos como alemães e franceses construíram a guerra, tal como deveria ser vista e vivida por seus concidadãos. O programa tornou-se um exercício socializado de compreensão e reescritura histórica, além de se colocar diante do conflito entre memória e história, questão que norteou a historiografia dos anos 1990. Este artigo analisa Histoire Paralèlle, observando a relação que estabeleceu com a produção historiográfica e fílmica do historiador. Para tanto, seus pressupostos teóricos são rediscutidos e historicizados à luz das obras de Ferro e por meio da análise de três dos seus programas.
\end{abstract}

Palavras-chave: Cinema; História; Marc Ferro; cinejornais.

\section{La construcción de la historia en la televisión: Marc Ferro y los cine-noticiarios en Histoire Parallèle}

\section{Resumen}

En 1989, cuando la Europa se transformaba con la caída del Muro de Berlín y la expansión de las comunicaciones por satélite surge La Sept, el canal de televisión franco-alemán. Histoire Paralèlle, un programa presentado por Marc Ferro con los cine-noticiarios vehiculados en ambos países, 50 años antes, se convierte en el programa más visto de la emisora, comparando por las imágenes las formas en que alemanes y franceses concibieron la guerra, tal como debería ser vista y vivida por sus conciudadanos. El programa se ha convertido en un ejercicio socializado de comprensión y reescritura histórica, además de estar delante del conflicto entre la memoria y la historia, una cuestión que guio la historiografía de la década de 1990. Este artículo analiza Histoire Parallèle, observando la relación que se establece con la producción historiográfica y fílmica del historiador. Por lo tanto, sus supuestos teóricos se rediscuten y contextualizan a la luz de las obras de Ferro y mediante el análisis de tres de sus programas.

Palabras clave: Cine; Historia; Marc Ferro; cine-noticiarios.

\section{Constructing history on television: Marc Ferro and newsreels in Histoire Parallèle}

\section{Abstract}

In 1989, when Europe was being transformed after the fall of the Berlin Wall and the expansion of satellite communications, $L a$ Sept, a Franco-German TV channel, came into being. Histoire Paralèlle, a TV show hosted by Marc Ferro with newsreels shown in both countries, 50 years before, became the most watched program of the station, comparing the images the ways in which German and French started the war, as it should be seen and experienced by their fellow citizens. The program became a socialized process of understanding and historical rewriting, besides standing before the conflict between memory and history, a question that guided the historiography of the 1990s. This article analyzes Histoire Paralelle, examining the relationship that it established with the historiography and filmic production of the historian. Therefore, its theoretical assumptions are re-discussed and historicized in the context of Ferro's works and through the analysis of three of his programs.

Keywords: Cinema; History; Marc Ferro; newsreels.

\section{La construction de l'histoire à la télévision: Marc Ferro et les actualités en Histoire Parallèle}

Résumé

En 1989, lorsque l'Europe se transformait avec la chute du mur de Berlin et l'expansion des communications par satellite, se pose La Sept, la chaîne de télévision franco-allemande. Histoire Paralèlle, présenté par Marc Ferro avec des actualités montrés dans dans les deux pays, 50 ans avant, devient le programme le plus regardé de la station, en confrontant les façons dont les Allemands et les Français ont construit la guerre, comme elle doit être considérée et vécue par leurs concitoyens. Le programme est devenu un processus socialisé de compréhension et de réécriture historique, et sest placé devant le conflit entre mémoire et histoire, question qui a guidé l'historiographie des années 1990. Cet article analyse Histoire Paralèlle en regardant la relation établie avec l'historien de production historiographie et de films du historien. Pour cela, les hypothèses sont discutées et historicisées à la lumière de ses œuvres et à travers lanalyse de trois de ses programmes. Mots clés: Cinéma; Histoire; Marc Ferro; actualités. 
E xaminando arquivos fílmicos sobre a Primeira Guerra Mundial, em 1964, Marc Ferro percebeu que imagens continham informações distintas das que se conhecia por meio de documentos escritos. A partir dessa constatação, feita ao observar a alegria da população alemã com o armistício de 1918, quando ainda se desconheciam os termos da rendição, o historiador pôde entender a desilusão e o furor que se seguiu à ideia forjada pelo exército germânico de que seu país não havia perdido a guerra, mas tinha sido traído pelos adversários, argumento que alimentou as reações apaixonadas do conturbado período entre guerras. Logo depois, Ferro analisou filmes russos do início dos anos 1920, com situações inéditas sobre a vida na Rússia, que não correspondiam àquilo que se conhecia pela bibliografia. Daí derivaram suas primeiras reflexões teóricas sobre as possibilidades do cinema como fonte para o historiador, no momento em que passava a fazer parte da revista Annales.

Ainda que nada impedisse o estudo de filmes pelos historiadores desde que Seignobos e Langlois, ${ }^{1}$ em 1898, reconheceram que obras literárias ou teatrais permitem conhecer períodos de escassa documentação, foram muito poucos os estudiosos que enfrentaram os arquivos fílmicos ou mesmo os filmes de ficção até os anos $1960,{ }^{2}$ e foram poucos os que abriram e se enveredaram pelo campo do cinema como fonte para o estudo da História, com os desdobramentos que podemos observar hoje - já poupados de muitos dos seus constrangimentos, pois, nos anos 1970, marcados pelo marxismo nos estudos históricos, o cinema não era visto como documento de estudo confiável.

Foi, portanto, necessário legitimar o estudo do cinema pelos historiadores. Entretanto, aceito ou não, Ferro seguiu pesquisando história contemporânea, produzindo e analisando filmes $-{ }^{3}$ com suas observações sobre as imagens sendo incorporadas ao conhecimento histórico que produziu. A partir desses estudos, aprofundou suas reflexões historiográficas marcadas pelo viés comparativo, do qual a pesquisa com imagens foi um dos polos desencadeadores, uma vez que, ao invés de considerar que as imagens erravam quando seu conteúdo era distinto do que já se conhecia pela historiografia, lançava dúvidas sobre as construções já estabelecidas.

Dentre os vários trabalhos de análise e realização cinematográfica que desenvolveu, Histoire Paralèlle, programa de televisão que manteve entre 1989 e 2001 no canal La Sept, tornou-se significativo pela intervenção do historiador no espaço midiático. A emissão, fundada na exibição comparativa de cinejornais

\footnotetext{
'Charles Seignobos; Charles Victor Langlois, Introduction aux Études Historiques, Paris, Librairie Hachette, 1898. 2Sigfried Kracauer, De Caligari a Hitler. Rio de Janeiro, Jorge Zahar, 1988 [1947]; Edgard Morin, O cinema e o homem imaginário, Lisboa, Relógio d’Água, 1997 [1956] - dois autores que não são historiadores. Robert Mandrou, em "Histoire et Cinéma”, Annales E.S.C. vol. 13, n. I, Paris. 1958, p. 140, propõe uma história social através da frequentação das salas de cinema. Nos Estados Unidos, o enfoque aparece, sobretudo nos anos 1970, no já clássico Movie-Made America: a cultural history of American movies, New York, Ramdon House, 1975, de Robert Sklar, ou na revista Film \& History, de 1971.

${ }^{3}$ Nos anos 1970, dirigiu Images de l'Histoire, 13 filmes de 13 minutos para a Hachette - Pathé Cinéma com títulos como Lénine par Lénine (1970), entre outros. Institut Nacional de l'Audiovisuel (INA). Lénine par Lénine. Disponivel em: <http://www.ina.fr/histoire-et-conflits/revolutions-et-coups-d-etat/video/CPF86624225/leninepar-lenine.fr.html>. Acesso em: 6 de março de 2014.
} 
dos países em litígio na Segunda Guerra Mundial, permitiu — e manteve, pela boa resposta da audiência - um exercício historiográfico público e contínuo, ao revisitar o passado recente dos dois países. No mesmo momento em que caía o Muro de Berlim e a Europa dava início a sua profunda reconfiguração, em que Pierre Nora fazia da memória, de seus lugares e das celebrações o centro dos debates historiográficos, a nova emissora franco-alemã promovia uma revisão histórico-memorialística conjunta do último grande conflito a opor suas populações. Os cinejornais vistos ou revistos pelo público tornavam-se, nessa operação, documentos acessíveis e compartilhados numa extensa e significativa difusão junto a um público médio em torno de um milhão e duzentos mil espectadores, ${ }^{4}$ o que fez de Histoire Parallèle o programa de maior audiência da emissora.

Em maio de 1989, havia começado a funcionar La Sept, canal público de televisão cultural franco-alemão presidido pelo historiador George Duby. O surgimento desse canal como uma "Sociedade Europeia de Programas de Televisão" marcava os laços de amizade que deveriam unir os dois países, inimigos de longa data. Em $1^{\circ}$ de setembro, Histoire Paralélle começou a ser apresentado por Marc Ferro e pelo historiador alemão Klaus Wenger, exibindo os cinejornais veiculados nos cinemas dos dois países naquele mesmo dia, 50 anos antes, quando se preparavam para a guerra.

A exibição integral dos dois cinejornais proporcionou o diálogo, acionou a memória, provocou emoções, surpresa. Conduziu à reflexão sobre a construção das narrativas históricas consagradas: o que cada país enfatizava de fatos comuns, como eram organizados, seu encadeamento temático, a retórica cinematográfica de que se nutriam: a construção fílmica, a voz off, ${ }^{5}$ o fundo musical. A guerra foi vista, revista e por muitos revivida, o que suscitou reações. A emissão, projetada para durar alguns meses, estendeu-se por 12 anos, quando chegou a abarcar todos os países beligerantes que colaboraram no envio de material fílmico, além de historiadores, especialistas ou testemunhas que vinham da Itália, Japão, Estados Unidos, Inglaterra e União Soviética para participar das discussões do programa. Terminada a difusão dos filmes da guerra, o programa se mantém e aborda o pós-guerra, a descolonização, a formação da União Europeia, entre outros temas, até que, em 2001, chega ao fim, devido à escassez de imagens de cinejornais nos arquivos, segundo Ferro. ${ }^{6}$

Não é fortuito, entretanto, constatar que um programa que revisitaria a história da Europa a partir de cinejornais começasse a se produzir no mesmo momento em que o continente se encontrava em forte ebulição política, a qual culminou com o desmoronamento do comunismo nos países do Leste

${ }^{4}$ Pesquisas de 1991 da Mediamat. Isso correspondia a 7\% da audiência francesa. Cf. François Garçon, "La réussite d'Histoire parallèle", Cinemaction, n. 65, Paris, 1992, p. 60.

${ }^{5}$ Termo cinematográfico que designa a narração realizada por alguém que não se encontra diante das câmeras.

'Laurent Veray, "De la BDIC à Histoire parallèle - regard d'historiens et de témoins sur les Archives”, Materiaux pour I'histoire de notre temps, n. 89-90, Paris, 2008/1-2, p. 147-155. Disponível em: <http://www.cairn.info/article. php?ID_ARTICLE=MATE_089_0025>. Acesso em: 5 de março de 2012. 
Europeu. Histoire Parallèle é parte dessa nova inscrição histórica da Europa. Mas é também o resultado do trabalho historiográfico de Ferro, em que a história contemporânea não pode ser dissociada da imagem e dos meios audiovisuais em sua produção e recepção. O cinejornal, elemento essencial da comunicação durante a guerra, a face do regime, sobretudo na Alemanha de Goebbels, tornava-se agora diante de todos, através da televisão, documento histórico para novas leituras. Visto de forma ampla e crítica, ele é resgatado e, assim, amplamente ressignificado, possibilitando novas reflexões.

$$
\begin{aligned}
& \text { Foram muito poucos os estudiosos que } \\
& \text { enfrentaram os arquivos filmicos ou mesmo } \\
& \text { os filmes de ficção até os anos } 1960
\end{aligned}
$$

Além disso, virtudes e limites do programa, como vamos apontar, testemunham as formas de tratamento dado ao cinema pelo historiador, tratamento de há muito já absorvido, criticado em seus limites e enriquecido por inúmeros historiadores em todo o mundo, inclusive no Brasil. ${ }^{7}$

Sendo assim, procuro neste artigo refazer alguns dos caminhos que levam Marc Ferro desde seus primeiros estudos com filmes a partir de 1964 até Histoire Paralèlle, um percurso de mais de 40 anos de reflexões, revendo e contextualizando a imbricação entre o trabalho com filmes - análise e realização - e

\footnotetext{
${ }^{7}$ Seria difícil resumir as muitas linhas em que se desdobraram esses estudos e suas repercussões que, desde os anos 1970 nos Estados Unidos e na França (para falar apenas desses) e, a partir dos anos 1990, no Brasil, aprofundam e criticam as reflexões de Marc Ferro, sobretudo a centralidade dada ao estudo do Cinema como fonte para o historiador ou a sua noção de contra-história. Obras como a de Robert Rosenstone, A história nos filmes - os filmes na história, São Paulo, Paz e Terra, 2010, ou de William Guynn, Writing History in film, New York, Routledge, 2006, alargam e atualizam essas premissas a partir de relações mais profundas e próximas com a história do Cinema e a análise fílmica, enfoque que interessa de perto a Michele Lagny, em textos como História e Cinema, In: René Gardies, Compreender o cinema e as imagens, Lisboa, Edições Texto \& Grafia, 2006, ou Antoine de Baecque, em seu L'Históire-Camera, Paris, Gallimard, 2006, ou ainda ao israelense Shlomo Sand em seu Le XXe siècle à l'écran, Paris, Seuil, 2002. Nessa vertente, alargam-se as fronteiras do que se entendia por história do Cinema com as pesquisas de François Garçon em De Blum a Petain, Paris, Le Cerf, 1984, ou de Jean Pierre Bertin Maghit sobre o Cinema francês durante a Ocupação alemã, os filmes de propaganda, em Les documenteurs des années noires, Paris, Nouveau Monde, 2004. No Brasil, Alcides Ramos, n'O canibalismo dos fracos, Bauru, Universidade do Sagrado Coração, 2001, aborda em profundidade as relações que se estabelecem entre Os Inconfidentes, filme de 1972, de Joaquim Pedro de Andrade, e a ditadura militar no Brasil, enquanto Sheila Schvarzman, em Humberto Mauro e as imagens do Brasil, São Paulo, Editora da UNESP, 2004, trata, através da obra do cineasta, da construção de imagens sobre o Brasil durante o período Vargas entre muitos e muitos outros trabalhos a se apontar no Brasil e fora dele. Como o foco é a representação da História, a reconstrução da História ou a influência sobre a História, os arquivos fílmicos e sua utilização não podem ficar de fora. Sylvie Lindperg, para citar apenas o seu último livro, La voie des images, Paris, Verdier, 2013, ou o espanhol Vicente Sanchez Biósca, com NO-DO: el tiempo y la memoria, Madrid, Cátedra, 2005, ou ainda Jaimie Baron, em "The Archive Effect", Projections, vol. 6, n. 2, 2012, nos trazem exemplos significativos. A par de tudo isso, aproximar o historiador dos estudos do Cinema vem mudando sua historiografia, como se vê em reflexões como Film history: theory and practice, de Douglas Gomery e Robert Allen, New York, Knopf, 1985, ou de Michele Lagny, De I' 'histoire du Cinéma: méthodes historiques et Histoire, Paris, Armand Colin, 1992 e muitas outras mais.
} 
suas contribuições historiográficas, para observar como incidem no programa de TV que apresentou e, a partir disso, analisar três emissões.

\section{Marc Ferro, História, Historiografia e Cinema ${ }^{8}$}

Quando se observam documentários de temas históricos que se utilizam de imagens de arquivo, nota-se frequentemente uma preocupação com o texto da locução e o testemunho dos entrevistados. As imagens parecem escolhidas, como ilustração da locução, de uma ideia que preexiste às imagens. Poucas vezes, até pela dificuldade com os acervos, a informação é estritamente visual e se sustenta sem um texto. Em 1918: le dénouement (o desenlace), ${ }^{9}$ realizado em 1968 por Ferro para o cinquentenário do armistício da Primeira Guerra Mundial, observamos imagens da volta dos soldados à França, à Inglaterra, aos Estados Unidos e à Alemanha. Se na imagem dos primeiros países a recepção é calorosa, no país vencido ela não é funesta como seria de esperar pelo que se conhecia por meio da bibliografia, fato que surpreendeu o historiador, como referimos antes. Pela sobreposição dessas diferentes imagens obtidas em cinejornais, Ferro construiu um argumento historiográfico: escreveu por meio de imagens, encontrou uma informação distinta daquela conhecida pela historiografia estabelecida, chamou a atenção sobre as suas possibilidades de análise e apropriação pelo historiador.

\section{Uma relação datada?}

A relação entre História e Cinema, tal como desenvolvida por Marc Ferro no início dos anos 1970, foi determinada pela natureza dos fenômenos que analisava, tais como a Revolução Russa ou o stalinismo, eventos marcados pela disputa política de sua construção historiográfica e pela vigilância à sua documentação. Os filmes lhe deram a possibilidade de penetrar em dados então difíceis de acessar por outras fontes.

Conforme a sua prática nos arquivos soviéticos, observou que o caráter artístico e ficcional do cinema dificultava o controle das instituições sobre seu conteúdo. Dificultava, sobretudo, o controle por burocratas acostumados a ver no som, e não na imagem, o verdadeiro perigo. O controle político incidia sobre o som, sobre o que os personagens diziam, enquanto a censura moral é aquela que corta o que o filme mostra. ${ }^{10}$ A natureza do cinema permitia que lapsos se evidenciassem. Se havia censura, havia também um conteúdo que escapava. E o cinema, baseado em imagens, permitia que esses fragmentos do não dito aflorassem, apesar dos controles.

${ }^{8}$ Retomo e atualizo aqui considerações do capítulo "Cinema, História e Marc Ferro", da minha dissertação de mestrado Como o Cinema escreve a História: a América e Elia Kazan, Universidade Estadual de Campinas, Campinas, 1994.

9NA. 1918: le dénouement. Disponível em: <http://www.ina.fr/histoire-et-conflits/autres-conflits/video/ CPF86606060/1918-le-denouement.fr.html>. Acesso em: 5 de março de 2014.

${ }^{10}$ Marc Ferro, La Révolution Russe de 1917, 2. ed., Paris, Flammarion, 1977, p. 18-39. 
Analisá-los permitia ao historiador acesso a uma documentação inédita e diferente daquela encontrável nos arquivos controlados pelo Estado ou pelo Partido Comunista. ${ }^{11}$

É visível nessa formulação historiográfica dos anos 1970 a influência da psicanálise, muito utilizada então como instrumental interpretativo do cinema, ${ }^{12} \mathrm{e}$ ainda a prevalência da noção de ideologia tal como era praticada nessa mesma década, com seus conteúdos ocultos, cabendo ao historiador desvendá-los, restituindo-os ao conhecimento histórico. No entanto, como vamos mostrar, na análise que Ferro praticou em Histoire Parallèle, não se trata apenas de um lapso - conforme ele nomeou em seus primeiros textos - , mas, como mostra ao analisar os cinejornais em 1989, de conteúdos distintos, inéditos, produzidos na imagem - o que é dado ao historiador perceber e autenticar. Veremos exemplos mais adiante.

Antes disso, em 1964, como consultor de um documentário sobre a Primeira Guerra Mundial, o contato com os cinejornais o levou a notar que "as imagens não produzem as mesmas representações do passado que os arquivos escritos".13 A partir do estudo de filmes soviéticos, passa a utilizar o cinema como fonte de outra história, o que permite criticar o conhecimento a partir de documentos escritos. La Révolution Russe de 1917: Octobre, naissance d'une societé contém amostras da abrangência desse procedimento, pois já utiliza as observações sobre os filmes como documentação, com o mesmo estatuto que se atribui a fontes tradicionais. Isso lhe permite "legitimar a imagem como fonte histórica em relação às fontes consagradas". ${ }^{14}$

\section{Cinema e História: uma história}

Hoje, há quase 50 anos do surgimento dos estudos sobre Cinema e História, já é possível analisar a historicidade de como e por que filmes começam a interessar os historiadores na França: "A historicidade obriga a inserir a história numa perspectiva histórica. Há uma historicidade da história que implica o movimento que liga uma prática interpretativa a uma prática social". ${ }^{15}$ Dessa forma, ao observarmos a historicidade do filme como objeto de estudo e fonte para o historiador, somos levados a repensá-lo à luz de sua própria gênese, onde se mesclam as ideias da Nova História, as suas contribuições, a realidade cultural e social pós-maio de 1968 e o próprio cinema que se fazia na época.

\footnotetext{
"Parte da argumentação de Marc Ferro, em Analyse de film, analyse de sociétés: une source nouvelle pour l'Histoire, Hachette, Paris, 1974, e em Cinema e História, São Paulo, Paz e Terra, 2010, livro que reúne artigos dos anos 1970 os quais se apoiavam nesse conceito.

${ }^{12}$ Veja-se a influência de Cristian Metz e de seu seminário na mesma École, além de suas publicações, como Essais sur la signification au Cinema, Paris, Klincksieck, 1968, ou Langage et Cinéma, Paris, Ça Cinéma, 1971. ${ }^{13}$ Alain Besançon et al . "L'expérience de la 'Grande Guerre”, Annales E.S.C., n. 2, 1965, p. 327-336. ${ }^{14}$ François Garçon; Pierre Sorlin, “De Braudel à Histoire parallèle”, Cinemáction, n. 65, Paris, 1992, p. 53. 15Jacques Le Goff, Enciclopédia Einaudi, Lisboa, Eunaudi, 1984, p. 159.
} 


\section{"Uma máquina burguesa"}

Nos anos 1970, em revistas como os Cahiers du Cinéma, o cinema era visto como uma "máquina burguesa", "lugar de produção da ideologia dominante e, portanto, de opressão". ${ }^{16}$

Em 1980, Jean-Claude Bernardet, em seu Oque écinema, explicita essas ideias:

A máquina cinematográfica não caiu do céu [...] No bojo de sua euforia dominadora, a burguesia desenvolve mil e uma máquinas e técnicas que não só facilitarão seu processo de dominação, a acumulação de capital, como criarão um universo cultural à sua imagem. ${ }^{17}$

Sem nos determos no mérito dessas afirmações, essas eram as formas críticas de ver o cinema na época, e ensaios dos Cahiers du Cinéma ou discípulos de Christian Metz, entre outros, buscavam, mediante a semiologia e a linguística, caminhos para a constituição de um cinema crítico e não burguês. Para tanto, os Cahiers da década de 1970 retomam cineastas russos, como Dziga Vertov ou Sergei Eisenstein, além de reflexões sobre a técnica cinematográfica - vista como burguesa, pois reproduzia a perspectiva renascentista e a ideia "natural" e, por isso, "real" do que se vê. "Técnica e ideologia" (n. 231), "O fetichismo da técnica" (n. 233) e "Política e luta ideológica de classes" (n. 234) procuravam se contrapor a essa visão hegemônica. Em 1974, o cinema engajado em lutas anti-imperialistas é tema preponderante: cinematografias do Brasil, do Chile e da Argélia são abordadas e, na série Anti-Retrô, a reescritura da história no cinema é questionada, sobretudo a da ocupação alemã na França, que começava então a se fazer, em particular com Lacombe Lucien (1974), de Louis Malle, onde "os fantasmas do petainismo e do colaboracionismo eram tratados", segundo os articulistas, de uma "forma burguesa".18

Para se situar nessas questões, a revista entrevistou Michel Foucault, "cujo trabalho sistemático é o de recolocar o que o texto oficial recalca, o que se agita escondido nos arquivos malditos da classe dominante. ${ }^{19}$ Foucault mostra que o que estava em jogo naquele momento era o controle sobre a memória popular, que vinha se exercendo desde o século XIX por meio da literatura e do ensino primário. Diante desse controle,

o saber histórico que a classe operária tem dela mesma não para de diminuir [...] Agora, a literatura barata não é mais suficiente. Existem meios mais eficazes que são a televisão e o cinema. E creio que (o controle pelo ensino, TV e cinema) foi uma maneira de recodificar a memória popular, que existe, mas que não tem nenhum meio de se formular. Então, mostra-se para as pessoas, não o que elas foram, mas o que devem lembrar que foram. ${ }^{20}$

\footnotetext{
${ }^{16}$ Cahiers du Cinéma, n. 218, Paris, Éditions de l'Étoile, 1970, p. 3-4.

17Jean-Claude Bernardet, O que é Cinema, São Paulo, Brasiliense, 1980, p. 15

${ }^{18}$ Pascal Bonitzer; Serge Toubiana, Cahiers du Cinéma, n. 25I-252, 1974, p. 4.

${ }^{19}$ Michel Foucault, "Anti-Retrô", Cahiers du Cinéma, n. 25I-252, 1974, p. 5.

20/bidem, p. 7.
} 
A revista esforçava-se por desmontar os mecanismos da linguagem cinematográfica, de modo a tornar claro o seu funcionamento e revertê-lo em favor de um cinema "consciente e engajado", detendo o controle sobre o "efeito de realidade" da imagem para a causa justa.

\section{O seminário "Cinéma et Histoire"}

É em meio a esses questionamentos e ao desígnio do historiador como alguém que devolve a história à sociedade, conforme Ferro, que se desenvolvia desde o início dos anos 1970 o seminário "Cinema e História", na École des Hautes Études en Sciences Sociales.

\section{Pela sobreposição dessas diferentes imagens obtidas em cinejornais, Ferro construiu um argumento historiográfico}

O cinema soviético, documentários e filmes nazistas, o cinema de Vichy ${ }^{21}$ ou de Elia Kazan são alguns dos temas nos quais as construções histórica e fílmica eram objeto de estudo.

Se o cinema estava sendo repensado na técnica, nos temas e no engajamento político, no seminário isso era retomado à luz da construção de visões de História, de informações inéditas, de versões. Assim, analisava-se não só como o filme era engajado - um "agente histórico", ${ }^{22}$ mas também como isso ocorria historicamente dentro e fora do filme: do engajamento ideológico à crítica histórica. Não se tratava de fazer do cinema uma arma ideológica, como a revista engajada pregava, mas de entender como isso se processava e entendê -lo também como uma "contra-análise”, veículo de uma construção histórica inédita e, sobretudo, dissonante. ${ }^{23}$

O estudo das relações entre Cinema e História, como se vê, é uma preocupação inserida no seu tempo, datada e localizada. Parte significativa dos textos de Ferro sobre o tema foi escrita nesse período e, com isso, carrega muito dessa ênfase revelatória há muito ultrapassada pela bibliografia e por seus textos posteriores.

Em 1975, as questões do desvendamento conformam o âmbito das pesquisas do historiador, pela natureza dos fenômenos que estudava e dos filmes que

${ }^{21} \mathrm{O}$ cinema de Vichy designa os filmes realizados por franceses com a colaboração das autoridades germânicas na parte ocupada pelos alemães na França durante a Segunda Guerra Mundial. ${ }^{22}$ Outra denominação utilizada em seus livros.

${ }^{23}$ Marc Ferro, "O filme: uma contra-análise da sociedade?", In: Jacques Le Goff; Pierre Nora (Orgs.), História: novos objetos, Rio de Janeiro, Francisco Alves, 1976, p. 199-215. 
observara: stalinismo, nazismo, filmes de Vichy — todos produtos da tensão entre o que se podia e o que se devia mostrar. Diante desse universo fílmico, onde os filmes procuram transmitir mensagens políticas e se apropriar da História, é possível entender o papel da noção de ideologia nesse universo conceitual para a compreensão do cinema.

Já em 1985, em A História vigiad $a,{ }^{24}$ a ênfase é quanto à apropriação e controle sobre a obra de História. A obra aborda os "focos" e as possibilidades destes na construção de visões pluralistas, indo dos silêncios e festas à memória popular e ao cinema. A multiplicidade de focos sucede a dualidade. A noção de controle sobre a História, de seus abusos, toma o lugar da ideologia e do desvendamento.

Ao tratar do Cinema como "foco" de visões de História, Ferro preocupavase com o tipo de construção que o cineasta era capaz de produzir. "Quando é capaz de uma análise autônoma, exprime sua própria visão do mundo, independente das ideologias e das instituições no poder". ${ }^{25} \mathrm{E}$ a contribuição desses filmes reside em serem capazes de colocar a História em questão e não apenas de valorizá-la pela encenação.

Révoltes, révolutions, cinéma, de 1989, ano marcado pelas comemorações do Bicentenário da Revolução Francesa, passa em revista revoltas e revoluções encenadas pelo cinema. Ferro aborda a historicidade das noções de revolta e revolução desde 1830 até a Revolução Chinesa e observa como, ao longo da História, o cinema as aplicou. No caso da Revolução Francesa nas obras do pós-guerra, observa "que os filmes franceses nunca lhe são completamente favoráveis [...] A revolução no cinema exerce a função da catástrofe que se abate na vida dos personagens, que interfere em sua vida pessoal..... ${ }^{26} \mathrm{O}$ interesse se desloca do significado dos filmes e de seu valor enquanto fonte para o modo como constroem a História:

O tema de um filme tem menos importância do que o seu tratamento. Os cineastas que tratam de um fenômeno revolucionário procuram valorizá-lo, ao invés de colocá-lo em questão. Mas a ação revolucionária dos cineastas se exerce de outra forma. ${ }^{27}$

Assim, a questão é "descobrir pelo imaginário uma via real para compreender a História e torná-la inteligível".28

Entre 1976 e 1981, Ferro realizou com Jean-Paul Aron a série de TV Une Histoire de La Médicine, ${ }^{29}$ com oito documentários sobre as epidemias, a abertura do corpo, a história das doenças, entre outros. Tratava-se de um docudrama ${ }^{30}$ com cenas ficcionais que reconstituíam questões exemplares,

\footnotetext{
${ }^{24}$ Marc Ferro, A História vigiada, São Paulo, Martins Fontes, 1988 [1985].

${ }^{25}$ François Garçon; Pierre Sorlin, “De Braudel à Histoire parallèle”, Cinemáction, n. 65, Paris, 1992, p. 172.

${ }^{26}$ Marc Ferro (Org.), Révoltes, révolutions, cinéma, Paris, Éditions Centre Pompidou, 1989, p. $32-33$.

27Ibidem, p. 34

${ }^{28}$ /bidem, p. 35

${ }^{29}$ INA. Marc Ferro: images de l'Histoire. Disponível em: <http://www.ina.fr/recherche/search?search=Images+de

+|\%C2\%B4Histoire+-+Marc+Ferro+\&vue=Video $\& x=12 \& y=12>$. Acesso em: 2 de dezembro de 2014.

${ }^{30}$ Docudrama ou docufição é um documentário com encenação na reconstituição de fatos.
} 
como o momento em que se começa a isolar os doentes e o surgimento do hospital. ${ }^{31} \mathrm{O}$ historiador adentra um novo campo, recorta e enquadra suas questões a partir das formas de intervenção da Medicina sobre o corpo. Ferro será ainda responsável pelo roteiro de Pétain, de Jean Marboef (1993), entre outros.

Nesse período, seus trabalhos abrangem estudos sobre a Rússia e a ex-União Soviética, assim como os países árabes, em especial as ex-colônias francesas, a história da França e, por fim, a reflexão constante sobre escrita da história. Todos esses aspectos, no entanto, nunca estiveram dissociados do estudo do audiovisual e de seu papel na constituição dessas histórias. Conduzir Histoire Paralèlle pôs em jogo essas várias questões e proporcionou novas descobertas sobre a história da Segunda Guerra Mundial, entre outras. ${ }^{32}$

\section{"História Paralela"}

\section{Os historiadores na mídia}

É conhecida a presença de novos historiadores como Jacques Le Goff, Pierre Nora e Emanoel Le Roy Ladurie na mídia a partir dos anos 1970. Desde a década de 1960, pelas circunstâncias locais de maior acesso à universidade, havia uma demanda por produções históricas. Não apenas livros ou romances de vulgarização, mas também obras de especialistas. Isso fez com que os historiadores da École des Hautes Études e dos Annales passassem a dirigir coleções em grandes editoras. Segundo Rémy Rieffel, essas publicações funcionaram como instâncias de legitimação e notoriedade, criando "uma rede de autocelebração eficaz". ${ }^{33}$ Em 1969, Le Monde des livres, caderno de livros do jornal Le Monde, abre duas páginas aos "Novos caminhos da pesquisa histórica" com artigos de Le Goff e Le Roy Ladurie, que se transforma em colaborador regular e intermediário entre o jornal e o meio universitário. Muitos historiadores passam a escrever nos jornais.

Os anos 1970 marcam o apogeu dessa influência, quando, segundo pesquisas de mercado, o público francês pegou o gosto pela leitura e pelas emissões de rádio de temas históricos. Em sondagem de 1977, 37\% do público dizia preferir programas desse tema a programas de variedades (35\%) e de esporte (23\%). ${ }^{34}$ Entre 1973-1989, 17\% dos franceses liam livros de história. Segundo o

\footnotetext{
${ }^{3}$ Laurent Veray, "De la BDIC à Histoire parallèle - regard d'historiens et de témoins sur les Archives", Materiaux pour I'histoire de notre temps, n. 89-90, Paris, 2008/1-2, p. 147-155. Disponível em: <http://www. cairn.info/article.php?ID_ARTICLE=MATE_089_0025>. Acesso em: 5 de março de 2012. INA. Les societés devant l'épidemie: l'impuissance et la peur. Disponível em: <http://www.ina.fr/economie-et-societe/viesociale/video/CPC81050031/les-societes-devant-I-epidemie--impuissance-et-la-peur.fr.html>. Acesso em: 3 de dezembro de 2012

${ }^{32}$ Cinema et Histoire, reeditado na França em 2003 (no Brasil em 2010), traz essas novas conclusões. Em História da Segunda Guerra Mundial, São Paulo, Ática, 1995, Marc Ferro mostra como as plateias dos países em conflito foram preparadas pelo cinema de ficção e cinejornais para o evento.

${ }^{33}$ Rémy Rieffel, "Les historiens, l'édition et les medias", In: François Bédarida (Org.), L Histoire et le Métier d'Historien en France, Paris, Maison de la Sciences de l'Homme, 1995, p. 57-73.

${ }^{34}$ Ibidem, p. 66.
} 
autor, "os indicadores convergem: o discurso do historiador responde a uma necessidade de um público ávido por se debruçar sobre suas raízes e o seu passado". ${ }^{35}$ Isso se devia, segundo Rieffel, à qualidade dos livros e à capacidade de comunicação de seus autores com um público amplo. Em 1978, surge a revista "de vulgarização de qualidade" Histoire, com 80 mil exemplares semanais, e criam-se coleções de livros de bolso dirigidas pelos mesmos novos historiadores, entre eles, Marc Ferro.

Mas eram em programas de televisão como Alain Ducasse raconte e Apostrophes, de 1975, que se comentavam os lançamentos de livros da semana, o lugar privilegiado de divulgação (e consagração) desses autores, permitindo inclusive o aumento das tiragens.

Embora a partir de 1985 seja perceptível o declínio do interesse pela História e a estagnação do número de leitores, seu prestígio é ainda suficiente para alçar George Duby à direção da franco-alemã La Sept. A escolha de Ferro para Histoire Parallèle, como especialista em história contemporânea com forte presença na edição de livros, de filmes e presença em TV e imprensa, não foi espantosa.

\section{O formato}

Histoire parallèle foi criado por Louisette Neil e André Harris. De início, Marc Ferro fazia comentários junto com o alemão Klaus Wenger. Depois, Ferro efetiva-se e o historiador alemão dá lugar a especialistas de diferentes nacionalidades que participam do programa, conforme a abrangência de países abordados nos cinejornais. A emissão acompanha o calendário a partir de setembro de 1939 no passado e no presente, pondo em relevo, a cada semana, os eventos significativos. O desenrolar do programa dependeu da cessão de arquivos, dos entrevistados e especialistas e da relação que se estabeleceu entre as imagens vistas e o presente vivido. Histoire Paralélle era transmitido aos sábados, das $19 \mathrm{~h} 30 \mathrm{~min}$ às $20 \mathrm{~h} 30 \mathrm{~min}$ e reapresentado na quarta-feira às 18h. Foi ao ar entre setembro de 1989 e junho de 2001, totalizando 630 emissões.

Originalmente, deveria durar até junho de 1990, ou junho de 1940, momento do armistício entre a França derrotada e a Alemanha, que passa a ocupar parte do território francês. Como o interesse do público é grande, o programa é mantido. No entanto, foi preciso buscar outros cinejornais, uma vez que um "exército derrotado não filma a sua derrota". ${ }^{36}$ Passam a utilizar arquivos britânicos e cinejornais produzidos em Vichy.

Os programas de 52 minutos de duração são preenchidos com 40 minutos de atualidades. As imagens predominam sobre os comentários. Os cinejornais, de início exibidos integralmente, devido à sua extensão, passam a ser entrecortados por comentários dos participantes.

${ }^{35}$ Rémy Rieffel, "Les historiens, lédition et les medias", In: François Bédarida (Org.), L 'Histoire et le Métier d'Historien en France, Paris, Maison de la Sciences de l'Homme, 1995, p. 66.

${ }^{36}$ Ibidem. 


\section{Análise de três programas ${ }^{37}$}

Devido à multiplicidade dos temas, à quantidade de informações e à diversidade de especialistas, optei por apresentar neste artigo os três primeiros programas. Neles está o formato que, com poucas alterações, será mantido e muitas das questões que serão abordadas. Farei a descrição deles pelo interesse de seu formato seriado, pelo conteúdo das imagens e pelas formas de intervenção dos historiadores, permitindo, assim, observar seu funcionamento, características, limites e contribuição.

No texto "Crítica das atualidades cinematográficas, História Paralela", 38 Ferro analisa essas e outras questões que envolvem o trabalho com os arquivos fílmicos: autenticidade do suporte material, os ângulos de filmagem - se o cinegrafista está diante de um alvo bélico inimigo, certamente a imagem foi encenada - até chegar à análise de conteúdo e outros procedimentos indispensáveis para esse trabalho quando observa que "as imagens fornecem uma espécie de energia de informação, que convém domar [...]." ${ }^{39}$ No entanto, não analisa a natureza do cinejornal, gênero seriado a meio caminho entre a informação, o entretenimento e a propaganda.

Além disso, como nessas emissões os especialistas não se detiveram sobre as formas cinematográficas que deram sentido ao conteúdo analisado (embora possam tê-lo feito em outras ${ }^{40}$ ), e lembrando que "o arquivo filmado é também um arquivo de maneiras de filmar,", acrescentei esse aspecto em minhas análises. Não se trata de uma análise fílmica, procedimento que escapa às possibilidades de um artigo; trata-se de pontuar, no interior dos cinejornais, dispositivos que criam sentidos visuais significativos com forte apelo a formas e gêneros ficcionais.

Os cinejornais, ou as atualidades, como eram chamados, surgem em torno dos anos 1910. São derivações do travelogue ${ }^{42}$ o filme de viagem, derivação, por sua vez, das apresentações das câmeras escuras e dos aparelhos ópticos originais do século XVIII, que, através de desenhos e, mais tarde, de fotografias, traziam ao espectador visões sobre o mundo "desconhecido", que era então, para os países europeus que produziam filmes, os países e culturas que colonizavam na África e no Oriente, tratados como "exóticos" ${ }^{43} \mathrm{O}$ cinejornal "o transcorrer do mundo impresso na película",44 gênero que vai se desenvolver até os anos 1970, é a derivação seriada desse mesmo olhar que transforma fatos em acontecimentos espetaculares e mescla com igual peso, ainda que ordenados hierarquicamente, a política, o fait divers, ${ }^{45}$ a moda e os esportes, seus temas principais. A propaganda é parte intrínseca de sua elaboração. Os telejornais atuais mudaram muito

37Histoire Parallèle não foi editada em DVD por dificuldades com os direitos autorais. Em 2010, tive acesso a algumas cópias dos programas.

${ }^{38}$ Marc Ferro, Cinema e História, São Paulo, Paz e Terra, 2010, p. 90-109.

39/bidem, p. 98

${ }^{40}$ Jean Luc Godard fez observações a esse respeito ao lado de Eric Hobsbawn no programa n. 561.

${ }^{4}$ Sylvie Lindeperg, La voie des images, Paris, Verdier, 2013, p. 27.

${ }^{42}$ Fernão Pessoa Ramos, Mas afinal... o que é mesmo documentário? São Paulo, SENAC, 2008, p. 57.

${ }^{43}$ Laurent Manonni, A grande arte da luz e sombra, São Paulo, SENAC, 2003, p. 57.

${ }^{44}$ Fernão Pessoa Ramos, op cit.

45"Fatos diversos”. Trata-se de uma expressão do jargão jornalístico que se refere a notícias não apresentadas em uma editoria por terem caráter inusitado e curioso. 
pouco essa configuração original, acrescentando a elas as reportagens ao vivo, o "aqui e agora", que aumenta os efeitos de credibilidade do gênero.

É nos efeitos de credibilidade que se sustentavam os cinejornais, na ideia do transcorrer transparente impresso na película, na urgência e no fabricado caráter de imediatismo de que nem mesmo o documentário expositivo gozava. Como lembra Fernão Pessoa Ramos, quando surge, o documentário deve ser, segundo a denominação original de John Grierson, "a interpretação criativa das atualidades". ${ }^{46}$ No cinejornal, sobretudo sob o nazismo, havia interpretação dos fatos, mas o que aparecia na imagem e o que o formato do cinejornal autenticava (como acontece ainda hoje com os telejornais, por exemplo) era exatamente o contrário: unicamente a imagem dos fatos.

Emissão n. 1 -01/09/1939

Uma vinheta com imagens sobre a guerra abre o programa: soldados marchando, despedidas nas estações, crianças partindo, mulheres chorando. Hitler fala, uma bomba explode. $\mathrm{O}$ som com um ruído grave dá às imagens um caráter solene.$^{47}$ Marc Ferro começa a falar. Seu rosto está em $\mathrm{pp}^{48}$ sobre fundo branco e anuncia: “O cinejornal que vocês verão.... Apresenta o contexto do momento anterior à eclosão da guerra, quando as negociações de ingleses e franceses não surtem efeito junto aos alemães, e descreve o clima não belicista que envolve a França. Wenger apresenta o cenário alemão. Há emoção no ar, e Ferro fala de suas recordações sobre o período. O cinejornal da produtora Pathé é exibido na íntegra. Ferro comenta como o filme se constrói sob um clima ainda pacífico entre os franceses, ainda que o ataque surpresa à Polônia tivesse imposto a mobilização, diante da perspectiva do conflito. Aponta como o encadeamento de ações construídas pelo cinejornal estava referenciado às formas e acontecimentos da Primeira Guerra Mundial: preparo de barricadas, envio das crianças para o interior, distribuição de máscaras antigases. $\mathrm{O}$ foco está na retaguarda e na defesa. Nas imagens alemãs, ao contrário, Franz Wenger aponta como mostram o preparo para a guerra e criticam os inimigos ingleses e franceses pela intransigência nas negociações, motivo que os torna, na visão dos nazistas, os responsáveis pela eclosão do conflito. Nova vinheta fecha o programa com imagens da explosão do Reichstag, entre outras.

Emissão n. 2 - 07/09/1939

O formato e as vinhetas, que se mantêm até a última emissão, em 2001, estão presentes. Ferro dá o contexto da semana: em resposta à invasão da Polônia, Inglaterra e França declaram guerra à Alemanha no dia 3. Por que a demora? Os países haviam dado ultimato à Alemanha para se retirar do território polonês, o que não ocorreu. Além disso, as forças francesas eram menores do que as alemãs: "Os alemães são quatro vezes mais fortes do que nós, e nós sabemos disso, coisa que não será dita no cinejornal”, pontua o historiador.

\footnotetext{
${ }^{46}$ Fernão Pessoa Ramos, Mas afinal... o que é mesmo documentário? São Paulo, SENAC, 2008, p. 56. ${ }^{47}$ La 7 histoire parallele juillet 1990. Disponível em: <http://www.youtube.com/watch?v=O6Ss9ydsFSk>. Acesso em: 6 de março de 2014.

${ }^{48} \mathrm{pp}$ : primeiro plano.
} 
O cinejornal da Pathé abre com a palavra "GUERRA" e descreve o quanto a França tem lutado pela paz, com imagens do parlamento e dos ministros aliados em negociações inúteis diante da intransigência alemã. Imagens de multidões na rua comprando jornais. A chamada dos reservistas na França, Inglaterra e Holanda expõe uma multidão de homens nas estações férreas. A música pontua gravidade e urgência. Homens fardados beijam os filhos no colo das mulheres que choram. Da janela do trem, acenos dos soldados que partem. Nas cidades, as precauções contra ataques aéreos. As crianças recebem máscaras antigases. No parlamento, votação de recursos para a entrada na guerra. O arcebispo de Paris reza pela paz em torno de uma multidão de fiéis. Cenas no gabinete de Franklin Roosevelt, que pediu a retirada dos alemães da Polônia. "Todo o povo polonês responde ao agressor", diz a locução. Cenas de combate falam da agressão aos poloneses sem a declaração de guerra e do efeito surpresa da blitzkrieg (guerra relâmpago). "Ao invés dessa agressão cínica e bárbara, calmos, resolutos, os franceses respondem ao apelo da pátria”, diz a locução sobre a imagem de homens e mulheres lendo o chamado à mobilização. Na rua, as crianças são enviadas para o interior: "tudo foi previsto para o seu bem-estar e segurança". Enfermeiras colocam crianças em trens sob o olhar triste das mães. "Quem pode, deixa as cidades". Carros nas estradas, estações de trem lotadas, urgência enfatizada pela música. "O embaixador da Polônia na França coloca flores no monumento ao soldado desconhecido". "Os estrangeiros amigos da França vêm oferecer o seu apoio e auxílio". "São quatro mil que vão se alistar na Legião Estrangeira”. Outras notícias falam de medidas como a substituição dos homens mobilizados por mulheres e idosos, garantindo, assim, a normalidade da vida cotidiana. As cenas são enquadradas geralmente em planos gerais e médios. São curtas e se sucedem rapidamente. Ao contrário delas, a locução é pausada e arrebatada, acompanhada de fundo musical emotivo.

Novo segmento se abre com a imagem: "O QUE ELE DISSE”, e os vários atos de Hitler desmentindo suas promessas com "O QUE ELE FEZ". Em resposta a isso, as imagens mostram fusões entre símbolos franceses como o Arco do Triunfo ou a Catedral de Notre Dame e homens marchando, acompanhados de som marcial, páginas dos jornais com as manchetes e a voz off que fala da colaboração com a Inglaterra e seu Primeiro Ministro, o qual declara lutar contra a injustiça e a opressão. Como se vê, são imagens e discursos produzidos em estúdio com stock shots (acervo de cenas gravadas). A única informação original é o áudio da declaração de Chamberlain. Já o discurso de Daladier, o presidente do Conselho francês, é mostrado através da imagem de homens e mulheres nos bares ouvindo rádio — imagens de arquivo. Dele se ouve um pequeno extrato. Não há nenhum uso retórico dessa fala oficial, que sequer foi filmada. No final, ao contrário, versos d'A Marselhesa são recitados pausadamente - "Allons enfants de la patrie, le jour de gloire est arrivé" — sobre imagens de soldados, aviões militares em ação, canhões, navios, marinheiros e soldados marchando. Ao chegar na parte "Aux armes citoyens", o filme mostra soldados das colônias até finalizar com cenas do exército marchando, tomadas em contra-plongée ${ }^{49}$ com o hino agora cantado emocionadamente sobre ícones de heroísmo do monumento do Arco do Triunfo em pp. "FIN".

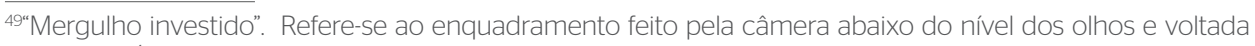
para cima. É a "câmera baixa" e seu principal efeito é engrandecer o objeto enquadrado. 
Wenger fala:

Até o dia 4 de setembro o Reich mantém as negociações, cujo único objetivo era fazer crer à sua população que os aliados foram os responsáveis pela declaração de guerra. Mas Hitler queria acabar com a Polônia desde abril, quando ordenara a preparação da guerra contra a Polônia para o 1/9. Enquanto isso, em Danzig, ${ }^{50}$ os SS [corpo de elite do partido nazista] simulavam provocações contra instalações alemãs, como se fossem poloneses, criando o pretexto para os combates.

No jornal da Universum Film-Aktien Gesellschaff(UFA) - estúdio cinematográfico alemão - , cenas das consequências desses ataques: o enterro de alemães e o choro das mulheres com crianças no colo. Populações alemãs "aterrorizadas", conforme a locução. A câmera pega em pp uma criança triste, uma mulher circunspecta, um velho. As imagens são individualizadas, pausadas - a câmera se detém; não se sucedem com rapidez na montagem. Um incêndio; a voz off explica que foi um ato polonês. Música dramática. Escombros na cidade, a locução fala em provocação: "Em plena paz, os poloneses destruíram lares". Há até mesmo o depoimento com a voz de um homem que perdeu a casa e a família. Diz a locução: "vocês podem ver"; a câmera percorre a casa destruída.

\section{Desde a década de 1960, pelas circunstâncias locais de maior acesso à universidade, havia uma demanda por produções históricas}

O som de depoimento em cinejornais não era usual. Difícil de ser então obtido fora de um estúdio, pois demandava equipamento pesado. Fazê-lo, ainda que de forma simulada, dublada em estúdio, demonstra preocupação com o realismo das imagens, na medida em que constrói o suposto testemunho verídico in loco.

Diplomatas ingleses aparecem na imagem andando por Londres, e o comentário da locução é sobre a sua falsidade, o rompimento de promessas e as mentiras velhas de 20 anos. "Por isso o ataque de 1/9 restabeleceu a paz e os direitos dos cidadãos alemães em Danzig”. Vemos imagens de tanques, conflitos sempre atribuídos aos poloneses, o som dos tiros, incêndios, gritos, vozes, sons acrescentados na edição. "Enquanto isso, em Berlim, Hitler esperou em vão por um negociador polonês com uma proposta de paz". Na imagem, Hitler chega ao Reichstag. Em Danzig, imagens em plano geral de soldados que comemoram. As tropas entram na cidade e são aplaudidas pela multidão. Ouvem-se gritos de júbilo e palavras de ordem (editadas, sobrepostas às imagens captadas in loco). Bandeiras nazistas nas janelas consagram a ocupação e compõem o cenário para a filmagem do desfile triunfal e da festa da ocupação da cidade polonesa pelo exército alemão.

${ }^{50}$ Danzig é a atual Gdansk polonesa. 
Novo segmento mostra as medidas de segurança na Alemanha, a exemplo do que se viu no cinejornal francês. Aqui, porém, a imagem se detém nos armamentos: a defesa antiaérea e os soldados que manejam aparelhos no terraço de um edifício de onde se domina a cidade tomada de vários ângulos. "Nossa indústria de armamentos está produzindo constantemente". Num plano geral da fábrica, veem-se tubos de metralhadoras, fuzis. A câmera faz um longo travelling ${ }^{51}$ lateral, mostrando todos os equipamentos fabricados; depois, uma grua em movimento toma a fábrica do alto, mostrando várias colunas de carros militares em fabricação. Tudo retilíneo, organizado e triunfal como no desfile filmado por Leni Riefenstahl em O triunfo da vontade (1934). A imagem da fábrica em plano geral, atravessada por outro travelling horizontal, onde se veem técnicos e operários pressurosos em seus aventais, trabalhando sob a supervisão de oficiais militares com seus uniformes, fecha esse segmento do filme, criando, sob a forma de uma linha de montagem ritmadamente orquestrada, a ideia da organização técnica competente, da ordem e do preparo. Os oficiais que percorrem as fileiras, no entanto, introduzem na iconografia e no gestual do que seria um supervisor de fábrica a guerra e a autoridade opressiva que emana da máquina de guerra nazista sobre todas as outras instâncias.

Enquanto isso, no campo de batalha polonês, tropas rompem o marco de fronteira com tanques, soldados a cavalo, motocicletas. Numa imagem tomada do interior de uma casa, vemos seus moradores de costas, saudando a passagem do exército alemão. O filme penetra no interior de uma feliz casa "liberada" (não vemos os seus rostos!). Música entusiástica. Do alto da montanha, um soldado alemão protege a chegada das tropas na planície. Combates. Cena de faroeste.

Em nova cena, imagens da força aérea: um aviador anda em meio a um céu enevoado, como que saído das brumas, como já fizera Riefenstahl com Hitler no início do seu filme de 1934. Ao fundo, uma sucessão de aviões enfileirados. Nesse cenário, a locução evoca os aviões poloneses destruídos em terra. Em pp, vemos os pilotos que se preparam para a partida e são enquadrados da mesma forma durante o voo. Depois, plano de conjunto dos aviões; abaixo deles, um rio. Um piloto atira. Ouvimos os tiros. Outro avião joga bombas. O filme se detém bastante tempo nessas imagens, que são bonitas. Na terra, cenas do bombardeio, e a narração fala das fortalezas polonesas desbaratadas. Imagens da cidade e fumaça das bombas que caem. Mas é sutil, de longe. Cenas de combates no porto onde se deu a tomada de Danzig a partir de navio alemão que bombardeou a cidade. "A população polonesa bateu em retirada" e vemos pessoas tomadas em plano americano andando por uma estrada com imagens de casas incendiadas, pontes destruídas, trens acidentados, cuja destruição é atribuída falsamente aos poloneses. "A população está agradecida. Seus dias de terror acabaram": vemos um homem que arranca placa de rua em polonês. Soldados alemães recebem comida da população, que não sorri.

Pela composição desse segmento de filmagens sobre o campo de batalha, constrói-se um pequeno filme de ação evocando o formato dos filmes de guerra, gênero que começou a se desenvolver antes da Primeira Guerra ${ }^{52}$ e onde, entre lutas, romances, o elogio às organizações militares ou a crítica à estupidez dos

\footnotetext{
${ }^{51}$ No travelling, a câmera se desloca no espaço, acompanhando uma ação.

52Pierre Sorlin, Cines europeos, sociedades europeas: 1939-1990, Barcelona, Paidós, 1996, p. 31.
} 
confrontos, os aviadores eram os heróis figurados como modernos cavalheiros e as filmagens de ação no ar, o grande espetáculo conforme se pode ver em Maudite soit la guerre, do belga Alfred Machin (1914) ou nas versões americanas em Wings, de William Wellman (1927), entre outros. ${ }^{53}$ Muitas dessas características são exploradas nessas cenas que se utilizam de tomadas de vários ângulos e lugares como a colina, a planície, no porto e no ar, compondo um retrato animado dos combates e construindo seus heróis.

Como se vê, há um bem planejado e montado encadeamento temático ritmado entre os acontecimentos no campo de batalha e aqueles produzidos na retaguarda, como mostra o "documentário" anterior sobre a indústria, por exemplo. Se há conflito, foi causado pelo inimigo. No campo de batalha, não há perdas ou feridos, só vencidos e vencedores. E, na retaguarda, preparam-se os armamentos para a continuação dos ataques, ou melhor, "da defesa".

Comentário de Franz Wenger:

Nas imagens alemãs não há guerra, é um contra-ataque; a Alemanha se defende dos ataques e provocações polonesas. Não foi a Alemanha que abriu os combates. Já as imagens francesas abrem com a palavra Guerra. Os franceses estavam conscientes da gravidade da situação?

Sim, responde Ferro: "Eles e os ingleses haviam declarado guerra à Alemanha, mas o que chama a atenção nas imagens da Pathé é o 'pacifismo escancarado' como se dizia, a atmosfera pacífica apesar do título do jornal". Para Wenger, algo semelhante ocorria na Alemanha, não havia entusiasmo,

havia uma ordem de Heydrich da SS para que a polícia e a Gestapo prendessem qualquer um que colocasse em dúvida a vitória da Alemanha. Ora, se isso era necessário, é porque a população não estava convencida da necessidade da guerra e da vitória.

Ferro observa que, nas imagens alemãs de cerimônias organizadas com autoridades, as imagens são de alegria, enquanto nas não organizadas, como as partidas nas estações, não há alegria como entre os franceses, o que evidencia a preparação das filmagens para esses eventos e o controle sobre as reações do público enquanto personagem atuante nas encenações. Mas, lembra Ferro, “os alemães não pensam que podem ser derrotados - acabavam de tomar a Polônia -, enquanto na França, o drama é que os franceses pressentem que serão derrotados, o que é um fardo muito pesado".

O que explica, diz Wenger, o tom otimista das atualidades Pathé. Temos a impressão de que o tempo dessas atualidades está atrasado em relação à opinião pública. Sim, diz Ferro, ela não fala do que é grave, como se evitasse fazer o espectador entrar no drama, como se houvesse uma espécie de cumplicidade entre o poder público que só fala de paz e as atualidades que não mostram o que está ocorrendo, o que é trágico! Do lado alemão, completa Wenger, as atualidades precedem a opinião pública. Elas anunciam medidas e dão o tom do tempo, o tom a ser seguido para viver, para enfrentar a guerra.

53Sobre o gênero, ver J. David Slocum, Hollywood and war: the film reader, Oxford, Routledge, 2006. 
Outro ponto abordado em ambos os cinejornais, lembra Ferro, é o Tratado de Versalhes, "violado" para os franceses e "traído" para os alemães. "Falamos da mesma coisa de forma invertida". Risos. Ferro:

\begin{abstract}
Ora, esse tratado foi inacreditável. Ele se baseava no direito de autodeterminação dos povos, o que é um belo princípio, mas abstrato, sobre o qual os franceses não refletiram. Não refletiram sobre o direito dos seus povos coloniais, por exemplo. E este seria aplicável a todos os povos, menos aos alemães, o que colocou uma grande responsabilidade para os vencedores. Grande injustiça feita aos alemães e aí havia uma diferença tão grande entre as palavras e os fatos que isso deixou os alemães enfurecidos.
\end{abstract}

Wenger observa: "Os alemães não achavam que haviam perdido a guerra, mas tiveram que assinar a derrota em Versalhes, pois o exército escondeu a derrota, e os nazistas usaram isso como se fosse má vontade dos aliados".

A emissão conduz à conjugação dos olhares sobre um mesmo objeto visto de pontos de vista distintos, à troca de impressões e revisões históricas a partir de ângulos distintos do campo de batalha, mas também à "compaixão pelo outro" de que fala Hanna Arendt. Assim fazendo, segue em direção a uma convergência de interpretações certamente necessária à conciliação do tempo presente - 1989 - do programa.

Emissão n. 3 - 14/09/1939

Introdução de Ferro sobre a derrota polonesa: "Os poloneses, que pareciam fortes, foram logo batidos pela guerra surpresa dos alemães, mas foram heroicos".

Nas imagens da Pathé, franceses, ingleses e belgas continuam a se mobilizar para a guerra. Estrangeiros se apresentam para lutar pela França, dentre eles tchecos, que, na fila, são empurrados pelos guardas franceses. Fait divers: elegância da mulher francesa com uma bolsa com a máscara antigases! Em meio às notícias sobre a Polônia, "Paris reencontra sua serenidade". Pessoas no mercado compram frutas.

Franz Wenger explica o rápido avanço alemão, pois a blitzkrieg destrói a aviação polonesa e as vias de comunicação para inviabilizar o ataque polonês. Com as forças alemãs, avança a propaganda antipolonesa e antissemita. Ele faz observações sobre as imagens da Noite de Bromberg, um ataque de poloneses à população alemã que resultou em cinco mil mortes. No cinejornal, se fala em “50 mil mortos assassinados pelos poloneses", o que serviu de justificativa para ataques do exército à população polonesa, como se pode ver nas imagens. No cinejornal, os poloneses presos terão "o justo castigo". Atribui-se a eles a destruição de pontes feitas pelos alemães. Mas "nosso gênio militar restabeleceu em tempo recorde para continuar o avanço”. Música épica.

Na imagem, uma série de velhos barbados de capote e bengala: são os judeus. Segundo a locução, "os judeus poloneses são culpados de inúmeras provocações e incitação ao assassinato de alemães. Entre eles, traficantes e criminosos que infiltraram a Alemanha desde 1918". Um demorado travelling lateral enquadra os velhos atônitos olhando para a câmera. A visão de homens frágeis, fracos e sujos 
não corresponde ao discurso ameaçador da locução, ainda que esse personagem filmado corresponda à iconografia largamente explorada em charges, cartazes e que será utilizada em "documentários" como Ojudeu eterno (Der ewige Jude), de Fritz Hippler, filmado em 1940 na mesma Polônia ocupada, onde se atribui a criaturas como essas a conspiração pela maléfica dominação mundial, justificando, assim, o extermínio que começaria a ser posto em curso naquele território. "Atualmente, os irmãos desses judeus do Leste estão na França e na Inglaterra, onde clamam pela eliminação dos alemães". Termina o travelling. Música em tom urgente. Campo de prisioneiros poloneses: estão sujos, maltrapilhos, feios, "acusados de furar os olhos de soldados alemães, fato negado pelos ingleses". Wenger já havia prevenido o espectador sobre as mentiras das imagens. Hitler, no campo de batalha, examina mapas do avanço do exército junto com oficiais. Anda por entre mulheres e crianças. O som é de uma multidão bradando como nos grandes espetáculos nazistas de antes da guerra.

\section{No texto "Crítica das atualidades c inematográficas, História Paralela", Ferro analisa essas e outras questões que envolvem o trabalho com os arquivos filmicos}

Surge nova cena em que soldados poloneses se dirigem para a câmera e se dizem felizes por não lutar mais por uma causa perdida que beneficia a Inglaterra. Atuam para o filme. Novamente, a voz testemunhal é invocada para agregar mais "verdade" à filmagem. Eles estão sem sapatos, com meias furadas, aceitando cigarros de soldados alemães, cumprindo para a câmera o papel humilhante de sub-raça que os nazistas atribuíam aos poloneses. Recebem pão e sopa em pp.

A ocupação alemã da cidade é uma festa. Os tanques passam pelas ruas já devidamente embandeiradas, e a população se movimenta em direção a eles acenando alegremente. São cenas compostas com movimento e ritmo. Os carros militares abertos entram pela rua em linha reta, tomados em leve contra-plongée, que ressalta os soldados em seu interior sendo saudados por mulheres, crianças e velhos que, ritmadamente, se aproximam dos veículos, fluindo horizontalmente em grupos alegres pelas ruas - a construção evoca cenas de um musical —, até confluir para onde estão os militares e ali formarem uma alegre coluna que saúda o avanço dos tanques pela cidade. Goebbels, como se pode notar, era um excelente diretor de cinema e coreógrafo e terá acompanhado o Führer em suas sessões cinematográficas no pré-guerra, quando eram vistos mais de cinco filmes por noite, entre eles, muitas produções americanas. ${ }^{54}$ A locução diz que a população alemã está, enfim, feliz depois de 20 anos de ingerência polonesa sobre a cidade. $\mathrm{O}$ cinejornal se fecha com uma multidão alegre, uma coluna de soldados e o som do hino alemão.

${ }^{54}$ Conforme Hitler, em Hitler, um filme da Alemanha, de Hans Jurgen Syberberg, 1977. 


\section{Comentário de Ferro:}

No jornal alemão, há a guerra, derrota, vítimas. Do lado francês, estamos no absurdo, no ridículo. Uma paródia da guerra de 1914 e não o drama da Polônia, que não aparece, salvo numa missa. A França está pedindo socorro a todo mundo.

Comenta o alistamento de tchecos que, na imagem, aparecem sendo empurrados com agressividade por policiais franceses.

"Na verdade", diz Ferro, "isso [o gesto] expressa a compreensão de que os franceses não têm motivos para entrar em guerra, mas que é por causa dos estrangeiros que terão de fazê-lo. É uma imagem premonitória do que será o Armistício e Vichy". Essa é uma reflexão como muitas do historiador que, na observação sutil das imagens, encontra esse tipo de evidência, cujo sentido não previsto ou desejado, em contradição com a locução, transborda da imagem, permitindo novas leituras. Aquilo que nos anos 1970 nomeava como "lapso" aparece agora como "energia de informações" das imagens que cabe ao historiador "domar".

Para Wenger, nas imagens da UFA, já estão inscritos os quatro principais temas da propaganda alemã durante a guerra:

A Alemanha é forte e vai ganhar; Hitler é o comandante supremo e, graças a ele, os soldados trazem a vitória; o exército alemão ocupa, mas é libertador: na Polônia, só há criminosos, judeus ou alemães; o antissemitismo. Esses temas serão desenvolvidos nos cinejornais a partir de um roteiro previsto e estabelecido por Goebbels.

\section{À guisa de conclusão}

Como se pode ver, a cada programa, a quantidade de informações nos materiais de arquivo e nos comentários é muito grande e, em muitos sentidos, inédita, pela sobreposição dos cinejornais e das pontuações que vão se compondo diante do espectador, das formas diferenciadas de enunciação, da ênfase dada aos assuntos e personagens, além das novas interpretações e informações que as discussões e os próprios embates entre a história e a memória suscitam. E suscitaram também reações apaixonadas e contraditórias de espectadores que criticaram justamente o formato do programa por trazer de volta essas imagens: "Seu trabalho é ignóbil, você reproduz a propaganda nazista, e como ela é mais forte do que você [grifo da autora], você faz com que as pessoas se tornem nazistas!" ${ }^{66}$ Reação que expressa não só a atração dos espectadores pela propaganda alemã, mas também, na suposta fraqueza do historiador diante da força das imagens, conflitos entre a memória e a história.

${ }_{55}^{5}$ Marc Ferro, Cinema e História, São Paulo, Paz e Terra, 2010, p. 98.

56/bidem, p. 102. 
Optei por trazer três programas consecutivos de 1939 para que se perceba como a série trabalhou a duração dos eventos em sua sucessão, repetição e reiteração. Isso permitiu resgatar e vivenciar o tempo próprio dos acontecimentos e como estes foram manipulados e reconstruídos pelos cinejornais, da mesma forma que, a cada semana, os especialistas iam juntos, acompanhados do público dos dois países, tomando parte nessa história que se reescrevia, no mesmo momento em que a história europeia também se transformava radicalmente; esse diálogo foi parte dela.

Como vimos, e Ferro pontuou, o cinejornal francês - produzido por uma empresa privada, a Pathé - está a reboque dos acontecimentos e trabalha ainda com um repertório sedimentado referido à Primeira Guerra Mundial e, se anuncia algo, é até pela omissão: a catástrofe que o armistício consagrou. Suas imagens são desordenadas, sem controle e preparo prévio. $\mathrm{O}$ cinejornal francês não produz seus eventos, e o seu papel de arregimentação social sequer havia sido pensado pelo governo francês. Já no alemão, o uso do cinejornal que já antecipava e preparava a guerra foi rigorosamente planejado, como se pode ver pela construção e manipulação dos acontecimentos, que é clara do início ao fim. No mais, a orientação de Goebbels sobre a sua elaboração, conforme alude Franz Wenger, é perceptível, como espero ter deixado claro por algumas pontuações sobre a forma de encenação, os temas, a maneira de abordá-los e o seu encadeamento pela montagem, o uso de recursos como o som e a voz dos testemunhos.

Os historiadores se detêm mais sobre o conteúdo histórico das imagens, e Ferro, sobretudo, pela comparação, chega a novas evidências sobre o desenrolar da guerra. É basicamente o seu método de trabalho. A discussão final é a mais densa e pode sair do âmbito exclusivo daquilo que é sugerido pelas imagens, ensejando questões que subjazem às narrativas ali inscritas.

As pontuações ou contextualizações não tomam o espectador pela mão. Há um suposto saber do público, que é respeitado. Ele não é visto como um ignorante que é preciso orientar e conduzir. Não é necessário indicar didaticamente - "veja isso, veja aquilo" - e, assim, fecha-se o sentido. É claro que houve uma pré-produção com os materiais que antecedeu cada emissão, prevendo o seu bom andamento, ritmo, diálogo com a audiência etc.

O programa vai na direção oposta da intensa produção de filmes de reconstituição histórica, séries de TV ou docuficções sobre a Segunda Guerra Mundial, muito comuns na Europa e, em especial, na França nos últimos 20 anos, onde o interesse e o dever de memória em relação ao Holocausto, ou o desconforto com a Ocupação, vêm justificando reiteradas produções, sob a alegação de que se deve alertar as novas gerações contra a repetição desses fatos. ${ }^{57}$ Essas produções comerciais, que, no mais das vezes, existem para dar um sentido suportável a acontecimentos de difícil aceitação, têm se pautado, na sua

${ }^{57}$ O seriado Un village français sobre a Ocupação e a Resistência, exibido no Brasil pela TV5 Monde, é um bom exemplo desse tipo de produção. Disponível no YouTube e para download em: < https://www.youtube. com/results?search_query=Un+village+français++>. Acesso em: 25 de setembro de 2014. 
encenação, "pela uniformização das formas de escrita da história numa estética de hipervisibilidade, imersão nos efeitos de imagem e som, pulverização da duração e nivelamento da temporalidade".5 Já Histoire Parallèle optou pelo trabalho sobre os cinejornais como documentos de época. Ao invés de aproveitar essas imagens como matéria-prima para uma produção midiatizada, restituiu aos espectadores o documento, na íntegra ou pouco editado, e, com isso, a prática seriada de esperar pelas imagens uma vez por semana na tela de TV, como acontecia nas salas de cinema em 1939.

Por outro lado, isso aponta para o tratamento dado pelo historiador aos embates entre memória e história naquele momento. Se pensarmos que esses filmes a que nos referimos são a construção de uma memória "prótese", conforme Foucault em suas observações sobre as mídias apresentadas anteriormente, nas emissões analisadas, ao contrário disso, está se configurando um modo de os historiadores controlarem o fluxo memorialístico, por meio de análises mais distanciadas dos cinejornais.

Por fim, o título Histoire Parallèle define bem o caráter da emissão: transformação do arquivo em matéria de reflexão (o sentido das imagens é reaberto e recolocado). Através dela, os historiadores consagram nesse momento um sentido para a nova Europa: o diálogo em lugar do conflito. A releitura das imagens opõe-se ao sentido original: trata-se de compreender o outro em lugar de combatê-lo. O cinejornal, originalmente exibido só para o público de cada país, ganha uma nova dimensão com a televisão binacional: os espectadores devem simultaneamente receber as imagens produzidas por seus próprios governos e pelo do inimigo, confrontá-las, atritá-las, buscar o sentido do passado e tentar construir um novo sentido para suas relações.

Histoire Parallèle define-se também pelo trabalho historiográfico de Marc Ferro com a História e as imagens, mas não só. Se ele foi um dos primeiros a utilizar o Cinema da mesma forma e com o mesmo estatuto que se dava a outras fontes, fez da exposição e discussão da multiplicidade e contraposição de fontes e versões que se entrecruzam, encobrem e instituem, sua forma privilegiada de resgate e entendimento histórico. Expôs as tensões e embates que marcam a construção da história e o poder contemporâneo que se exerce sem trégua sobre ela nas mídias, como se pôde acompanhar no programa que comandou. Esses três diálogos de 1989, que se repetiriam ainda por 12 anos, demonstram a que ponto a novidade historiográfica introduzida por Marc Ferro permanece atual, malgrado a evolução que os estudos sobre a relação entre o Cinema e a História tem conhecido desde os anos de 1970.

58Sylvie Lindeperg, La voie des images, Paris, Verdier, 2013, p. 7. 